\title{
Harmonic Measurement and Passive Filter Simulation using MATLAB
}

\author{
D C Bhonsle, Dr R B Kelkar
}

\begin{abstract}
Power quality is becoming a major concern of today's power system engineers. Harmonics play an important and major roll in deteriorating power quality, called harmonic distortion. Harmonic distortion is measured in terms of THD (Total Harmonic Distortion). This paper presents harmonic field measurement in power distribution network. The specific case study has been conducted at $\mathrm{C}$ K Pithawalla college of Engineering and Technology, Surat, Gujarat. It includes nonlinear loads such as-personal computer, LCD, laptop, etc. Harmonic measurement was conducted for individual loads. The selected distribution network is simulated using MATLAB software. Simulation and design of passive filter is presented in METLAB for harmonic mitigation. Results of the same are analyzed taking in to account IEEE standards limits for harmonic distortion.
\end{abstract}

Index Terms-Power Quality, Harmonics, Non-linear loads, Passive filter.

\section{NOMENCLATURE}

$T H D_{V}=$ Total Harmonic Distortion of voltage

$T H D_{I}=$ Total Harmonic Distortion of current

$h \quad=$ Harmonic Order

$n=$ Total Number of Harmonic Order

$V \quad=$ Voltage in volts

$I \quad=$ Current in amperes

$C \quad=$ Capacitance in farads

$L \quad=$ Inductance in henries

$R \quad=$ Resistance in ohms

$1=$ Fundamental Component

$F F T=$ Fast Fourier Transform

$B W=$ Bandwidth in $\mathrm{H}_{\mathrm{Z}}$

$S C R=$ Short Circuit ratio

$V_{f} \quad=$ Forward voltage

\section{INTRODUCTION}

$\mathrm{N}$ OWADAYS, power quality has become a great concern for both utilities and customers. With the increasing use of non-linear load being connected to the power system, more studies are needed. The problems associated with high harmonic content in the power system do not only result in the poor quality of supply but also the operation of the

D. C. Bhonsle, research scholar, corresponding author, is with the Department of Electrical Engineering, C. K. Pithawalla College of Engg. \& Tech., Nr Malvan Mandir, Dumas Road, Surat, Gujarat. (E-mail: dcb191020@yahoo.co.in).

Dr. R. B. Kelkar, Professor with the Department of Electrical Engineering, M. S. University, Baroda, Gujarat. system will get affected. The major sources of harmonics are from the three categories of equipment: power system equipments, industrial loads and domestic loads. Harmonic currents are generated to a small extent and low distortion level by generation, transmission and distribution equipments and to a larger extent by the industrial and domestic loads [1-5].

\section{HARMONIC FIELD MEASUREMENT}

Harmonic field measurement is done to verify the degree of severity of harmonic distortion due to domestic non-linear loads in the distribution system [9-11]. There are number of solid state controlled non-linear equipments are used for domestic application such as electronic fan regulator, personnel computer, printer, etc. These non-linear loads inject harmonic currents in the network thus distorting supply voltage.

In carrying out harmonic measurement at Faculty of Electrical Engineering Department of C. K. Pithawalla Collage of Engineering and Technology, Surat, six types of domestic application were selected. All the measurements are made at $230 \mathrm{~V}$ using Yokogawa make clamp on type Power Analyzer (200 A, $600 \mathrm{~V})$. Harmonic spectrum for each load is plotted showing magnitude of each harmonic frequency that makes up a distorted waveform. The magnitude of each harmonic frequency can be expressed as a percentage of fundamental. Total harmonic distortion is defined from harmonic spectrum as the ratio of the RMS sum of all harmonic frequencies to the RMS value of the fundamental.

Mathematically THD is expressed by the following equations [6-9]:

$$
\text { THD }=\frac{\sqrt{\left(\sum_{h=2}^{n} V_{h}\right)^{2}}}{V_{1}}
$$

$$
T H D_{I}=\frac{\sqrt{\left(\sum_{h=2}^{n} I_{h}\right)^{2}}}{I_{1}}
$$

\section{A. Electronic Fan Regulator}

The result from measurement of voltage harmonic spectrum and current harmonic spectrum of electronic fan regulator are shown in Fig. 1 and Fig. 2. 


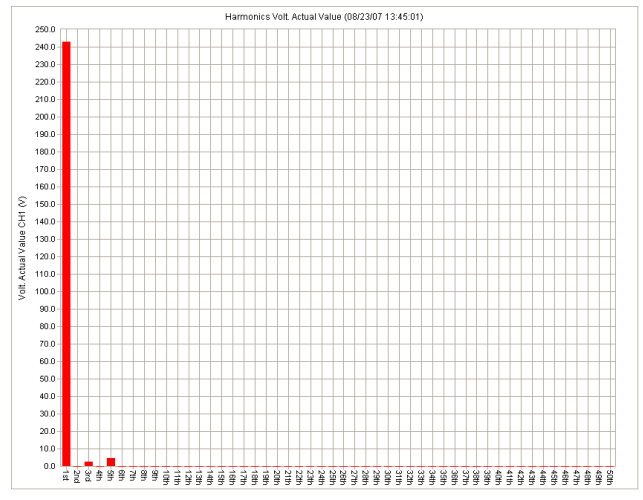

FIG. 1 Voltage HARMONIC SPECTRUM

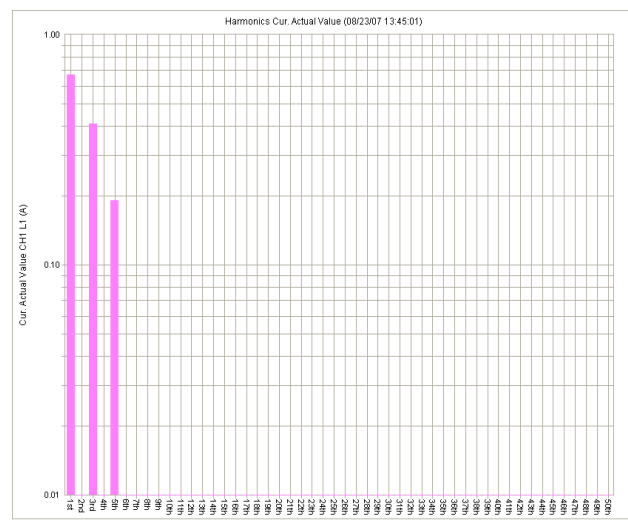

FIG. 2 CURRENT HARMONIC SPECTRUM

Total harmonic distortion for voltage and current can be calculated for electronic fan regulator using (1) and (2).

$T H D_{V}=2.2 \%$

$T H D_{I}=97.05 \%$

\section{B. Personal Computer}

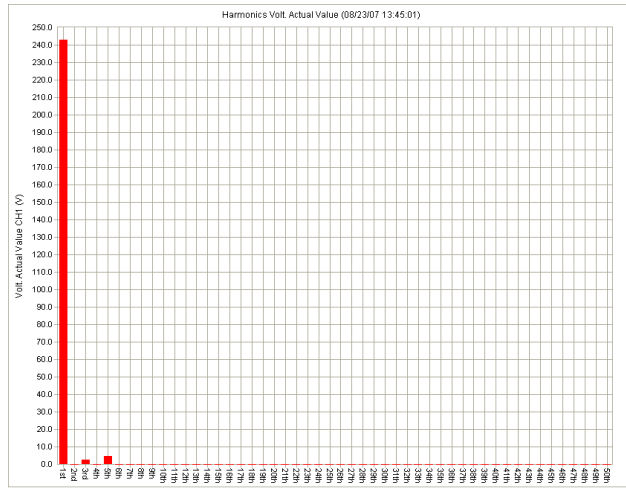

FIG. 3 VOLTAGE HARMONIC SPECTRUM

Similarly harmonic spectrum of personal computer for voltage and current are shown in Fig. 3 and Fig. 4 respectively. $3^{\text {rd }}$ and $5^{\text {th }}$ harmonics are predominant in current taken by personal computer.

Total harmonic distortion are calculated,

THD $=2.13 \%$

$T H D_{I}=67.44 \%$

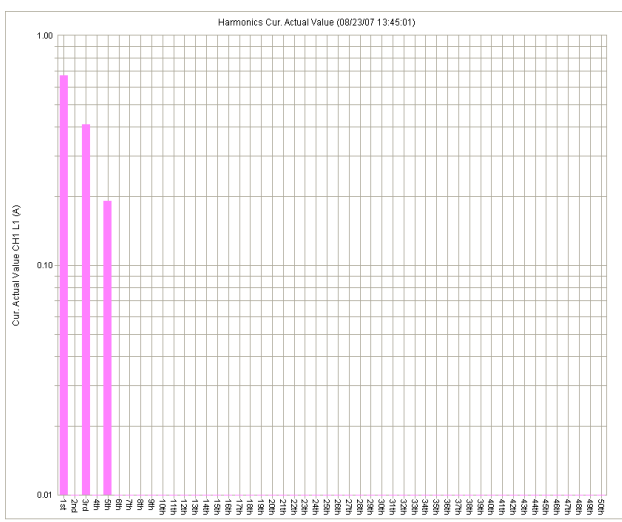

FIG. 4 CURRENT HARMONIC SPECTRUM

\section{Laptop}

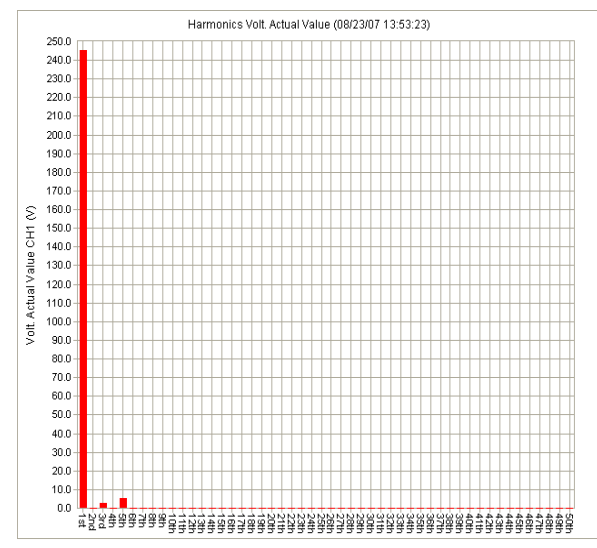

Fig. 5 Voltage Harmonic SPECTRUM

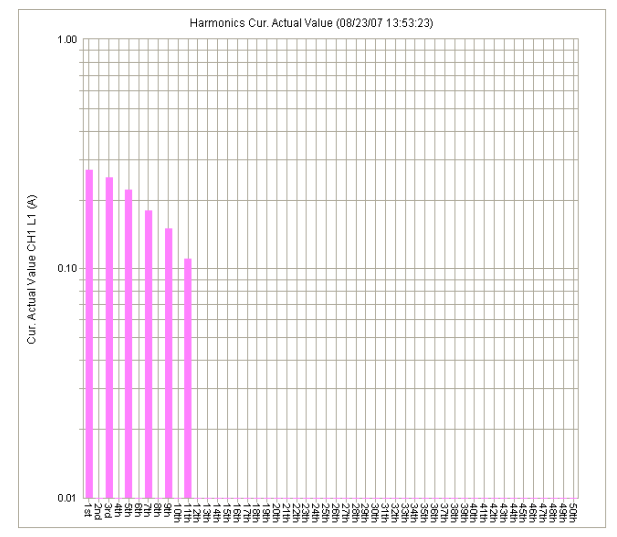

Fig. 6 CURRENT HARMONIC SPECTRUM

Current harmonic spectrum of laptop represents richness of harmonics present- $3^{\text {rd }}, 5^{\text {th }}, 7^{\text {th }}, 9^{\text {th }} \& 11^{\text {th }}$. THD calculated for voltage and current are,

$$
\begin{aligned}
& \text { THD }_{V}=2.44 \% \\
& T H D_{I}=156.2 \%
\end{aligned}
$$

\section{LCD Projector}

Total harmonic distortion for LCD projector is, $T H D_{V}=1.68 \%$

$T H D_{I}=12.19 \%$ 


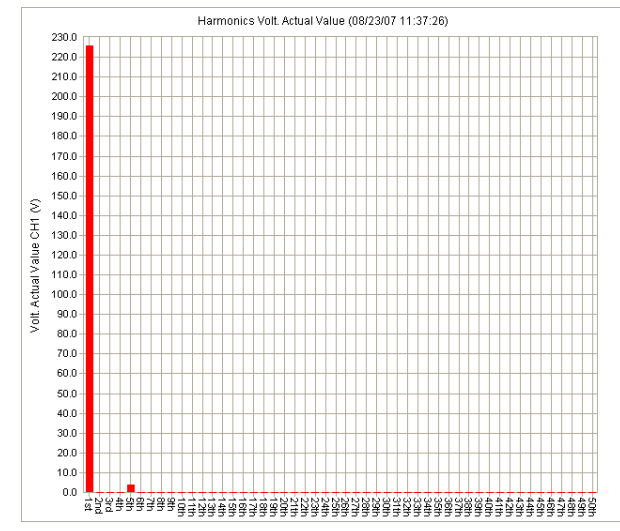

Fig. 7 VOLTAGE HARMONIC SPECTRUM

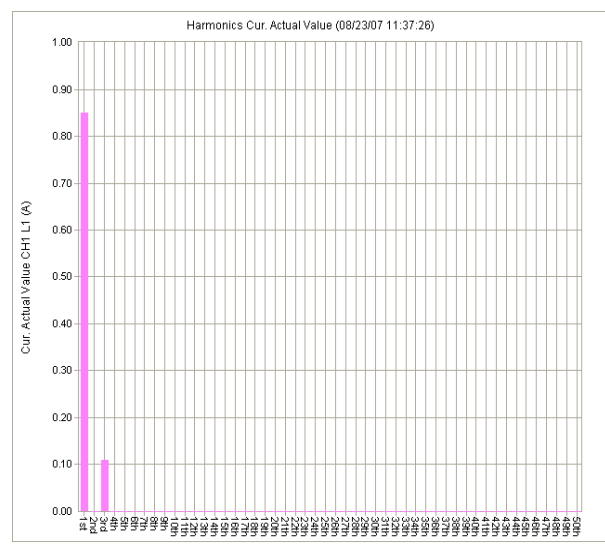

FIG. 8 CURRENT HARMONIC SPECTRUM

\section{SUMMARY}

\begin{tabular}{|l|l|l|l|}
\hline Sr. No. & Non-linear load & $T H D_{V} \%$ & $T H D_{I} \%$ \\
\hline 1 & Electronic Fan Regulator & 2.13 & 67.44 \\
\hline 2 & Laptop & 2.44 & 156.2 \\
\hline 3 & Fan Regulator & 2.2 & 97.05 \\
\hline 4 & LCD Projector & 1.68 & 12.9 \\
\hline
\end{tabular}

Fig. 9 VOLTAGE AND CURRENT HARMONIC DistorTION OF DOMESTIC NON-LINEAR LOADS

The IEEE 519-1992 [12] has imposed limits on total harmonic distortion (THD), as shown in appendix. Fig. 9 shows that voltage distortion limits of non-linear loads are within limits. Current harmonic distortion ranges from 12.9 $\%$ to $156.2 \%$.

\section{HARMONIC SIMULATION}

The sources of harmonic can be simulated using MATLAB 7.2 Math Works 2006. Full wave Diode Bridge feeding a capacitor and a resistance in parallel is designed to simulate a non-linear load as shown in Fig. 10.

Standard FFT package of MATLAB is used to plot voltage, current harmonic spectrum and to calculate THD of the same. The results are shown in Fig. 11. While analyzing current harmonic spectrum of simulated non-linear load, it found that $3^{\text {rd }}, 5^{\text {th }}$ and $7^{\text {th }}$ odd harmonics are predominant. The subsequent subsection describes the procedure for designing single tuned passive filter for elimination of above said harmonics.

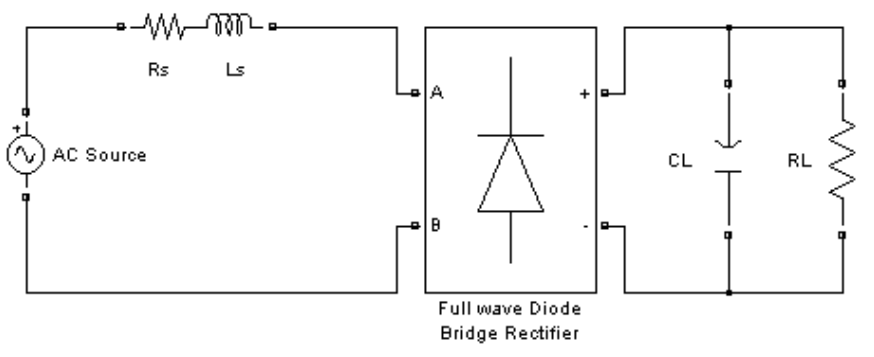

Fig. 10A NON-LINEAR LOAD SIMULATION USING MATLAB

\section{Design of Single Tuned Passive Filter}

The single tuned filter is designed to trap $3^{\text {rd }}, 5^{\text {th }}$ and $7^{\text {th }}$ harmonics by adding reactor with $X_{L}=X_{C}$ at the tuned frequency $(n \times f)$. The data required for the single tuned passive filter and the required procedural steps are described below:

\section{A. Data required for the design:}

1. Reactive power consumed : $Q$ in VA

2. Supply Voltage : $V_{S}$ in Volts

3. Supply frequency : $f$ in $\mathrm{H}_{\mathrm{Z}}$

4. Natural Frequency $: f_{n} \quad$ in $\mathrm{H}_{\mathrm{Z}}$

5. Harmonic order $: h \quad$ in Number

6. Quality Factor $\quad: Q_{L} \quad$ in Number

\section{B. Procedural steps:}

1. $X_{C}=\frac{V_{S}{ }^{2}}{Q} \cdot \frac{h^{2}}{\left(h^{2}-1\right)}$

2. $C=\frac{1}{\left(2 \times \pi \times f \times X_{C}\right)}$

3. $X_{L}=\frac{X_{C}}{h^{2}}$

4. $L=\frac{X_{L}}{(2 \times \pi \times f)}$

5. $R=\frac{h \times X_{L}}{Q_{L}}$

6. $B W=\frac{f_{n}}{Q_{L}}$
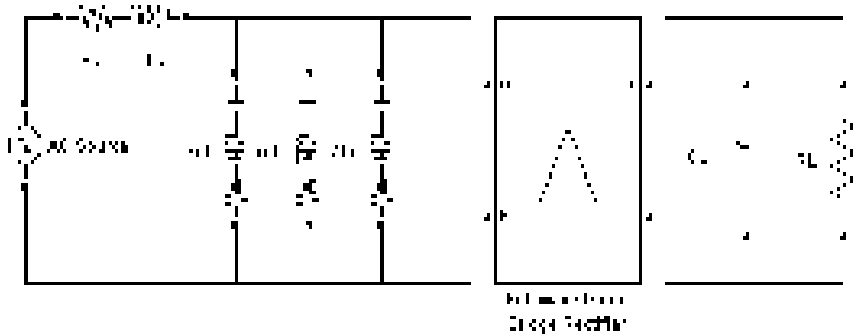

FIG. 10B Single TUNED PASSIVE FILTERS FOR $3^{\mathrm{RD}}, 5^{\mathrm{TH}}$ AND $7^{\mathrm{TH}}$ HARMONIC 
Following above said procedural steps, three single tuned passive filters are designed to take care $3^{\text {rd }}, 5^{\text {th }}$ and $7^{\text {th }}$ harmonics and implemented in MATLAB with the simulated diode bridge non-linear load shown as shown in Fig. 10B. The FFT analysis with and without passive filter is compared in the fore coming section.

\section{RESULTS}

Fig. $11 \&$ Fig. 15 show the load current and load voltage before passive filter installation, Fig. 13 \& Fig. 17 show harmonic spectrum of load current and load voltage before passive filter installation respectively.

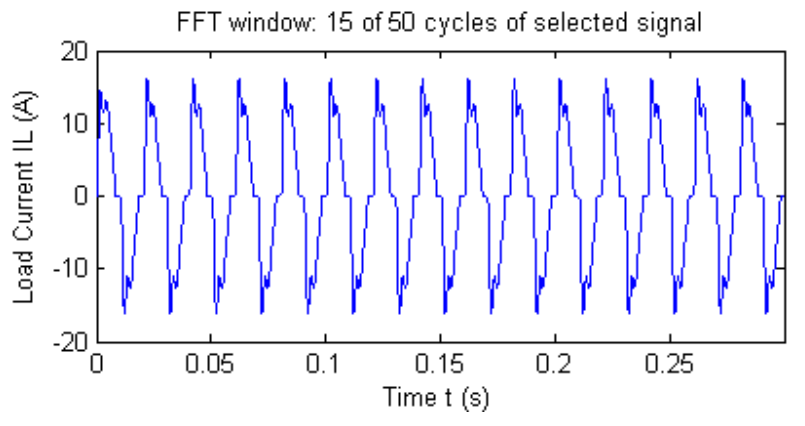

Fig. 11 LoAd CurRent without Single Tuned PAssive Filter

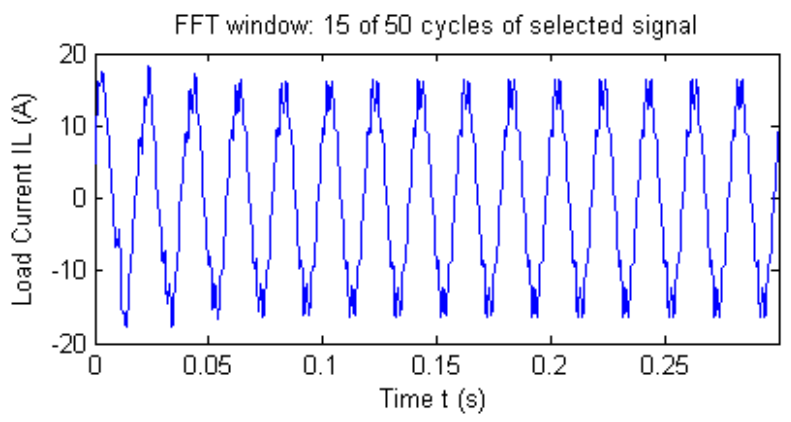

Fig. 12 LoAd Current with Single Tuned Passive Filter

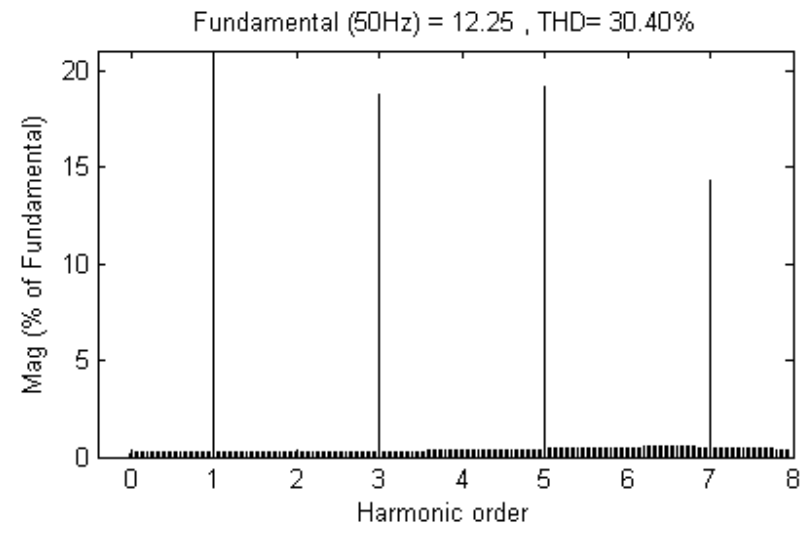

Fig. 13 CurRent Harmonic SPeCtrum without Single Tuned PASSIVE FILTER

The current harmonic distortion found is $30.40 \%$. Individual harmonic order THD is shown in the Fig. 25 which shows that IEEE limits for current harmonic distortion limits are violated.

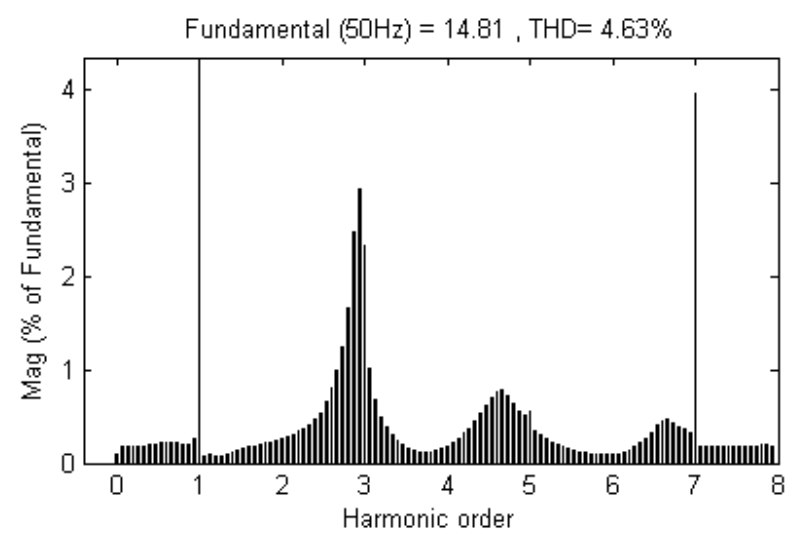

Fig. 14 Current Harmonic Spectrum with Single Tuned Passive FILTER

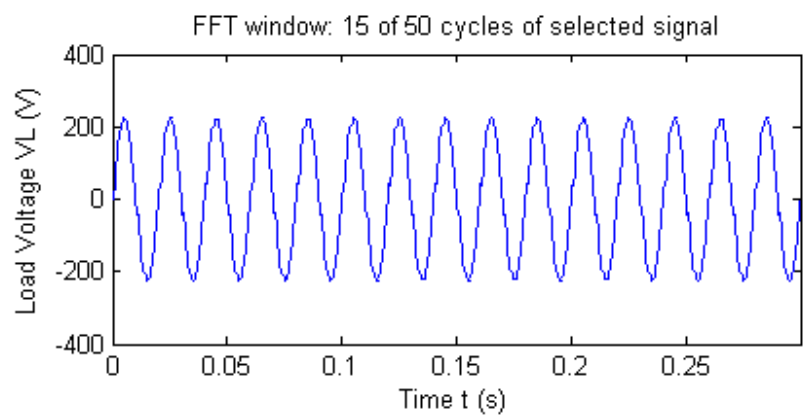

Fig. 15 Load Voltage Without Single Tuned Passive Filter

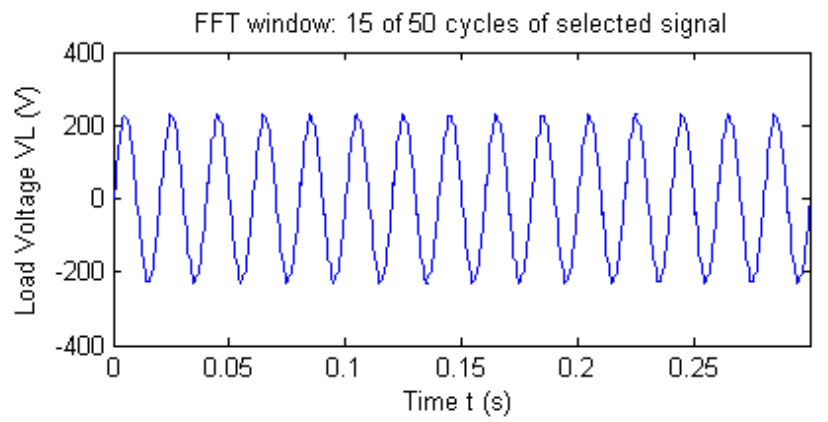

Fig. 16 Load Voltage With Single Tuned Passive Filter

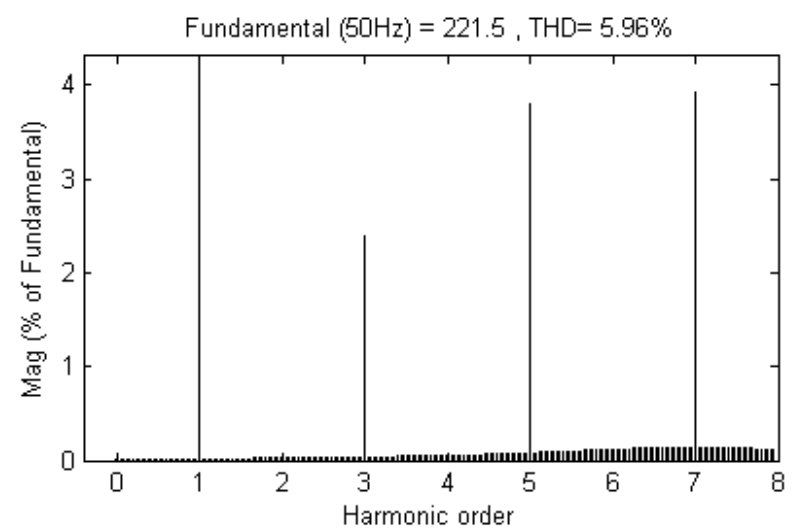

Fig. 17 Voltage Harmonic Spectrum without Single Tuned PASSIVE FILTER

The voltage harmonic distortion found is $5.96 \%$. Individual harmonic order THD is shown in the Fig. 26 which shows that IEEE limits for voltage harmonic distortion limits are violated. 


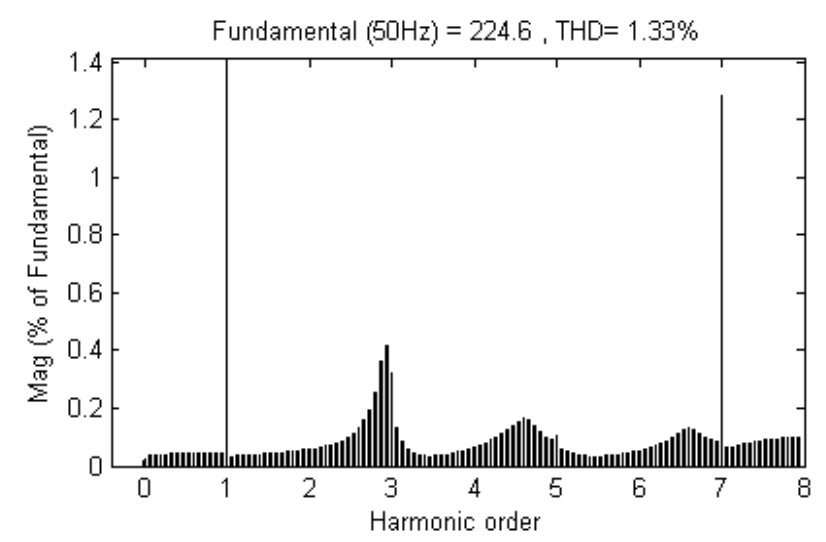

Fig. 18 Voltage Harmonic Spectrum With Single Tuned PASSIVE FILTER

Fig. 12 \& Fig. 16 show the load current and load voltage after passive filter installation, Fig. 14 \& Fig. 18 show harmonic spectrum of load current and load voltage after passive filter installation respectively.

FFT window selected for 15 of 50 cycles of selected current and voltage signals. Total harmonic distortion in current was reduced to $4.63 \%$ from $30.40 \%$ after passive filter installation. Whereas voltage harmonic distortion is reduced to $1.33 \%$ from $5.96 \%$ after passive filters installation.

Moreover considerable reduction in the total harmonic distortion in the respective order of harmonic is noticed, tabulated at the end of this section, shown in Fig. 25 \& Fig. 26.

Fig. 19 describes almost zero impedance offered for the $3^{\text {rd }}, 5^{\text {th }}$ and $7^{\text {th }}$ ordered harmonics.

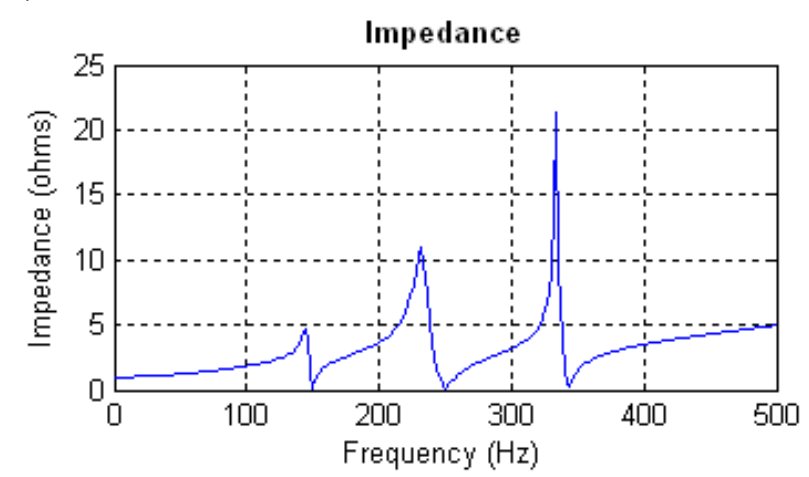

FIG. 19 IMPEDANCE AND V/S FREQUENCY OF PASSIVE FILTER

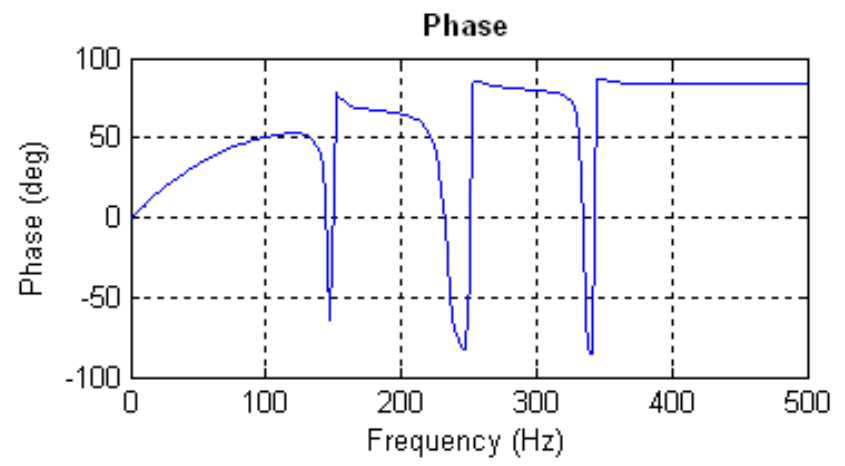

Fig. 20 Phase V/S FreQuency OF PASSIVE FILTER

Fig. 20 shows phase relationship at the $3^{\text {rd }}, 5^{\text {th }}$ and $7^{\text {th }}$ harmonic frequencies.

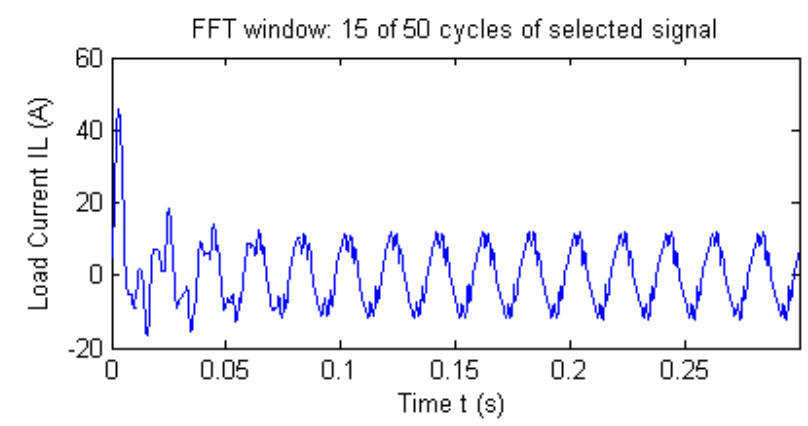

Fig. 21 LOAD CurRent with Single Tuned Passive Filter Under CHANGED LOAD CONDITION

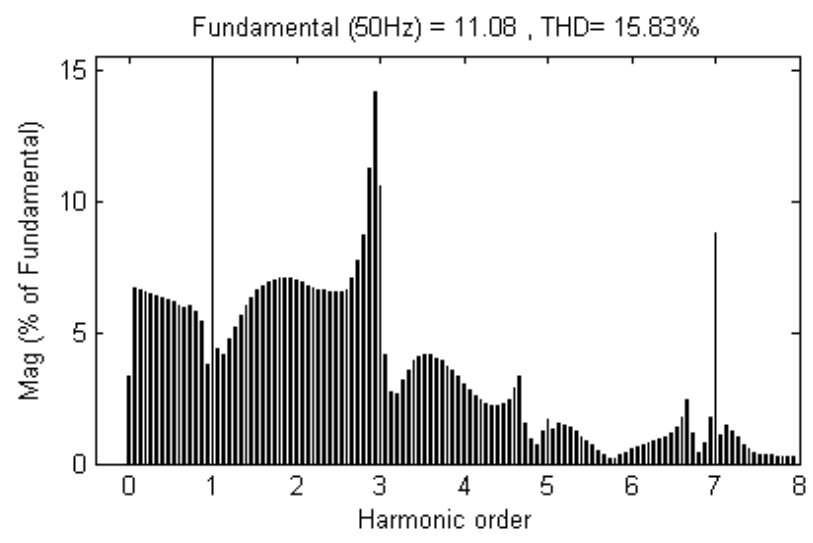

Fig. 22 Current Harmonic SPECTRUM With Single Tuned PASSIVE Filter Under CHANGEd LOAD CONDITION

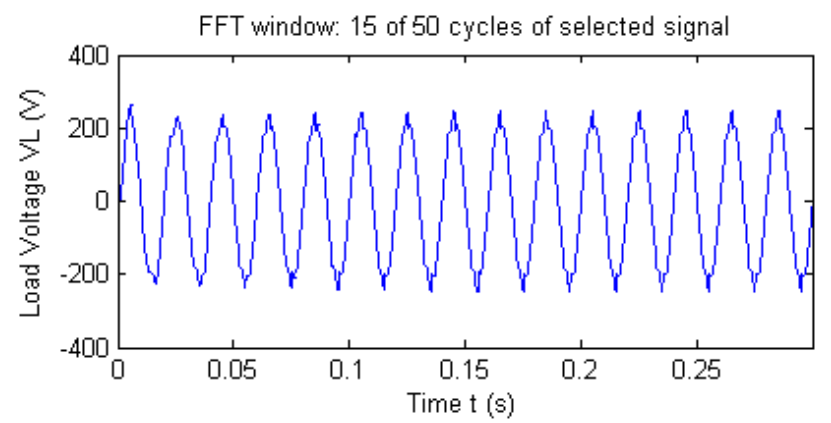

Fig. 23 LOAD VOLTAGE WITH Single TunEd PASSIVE FILTER UNDER CHANGED LOAD CONDITION

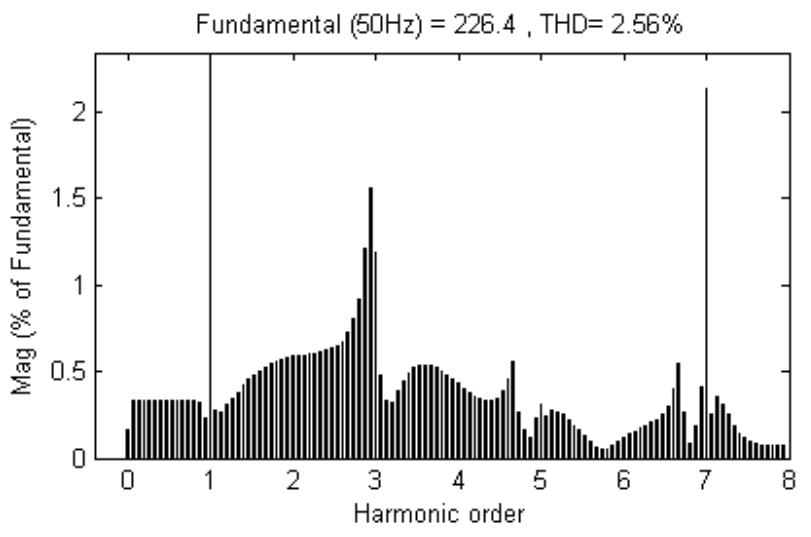

Fig. 24 LOAd Voltage Harmonic SPECTRUM With Single Tuned PASSIVE FILTER UNDER CHANGED LOAD CONDITION

Single tuned passive filters result in detuning subjected to load change. In the presented simulation load current is changed from $14.81 \mathrm{~A}$ to $11.08 \mathrm{~A}$ by changing load circuit parameters. Fig. 21 \& Fig. 23 represent the load current and load voltage waveforms, Fig. 22 \& Fig. 24 shows harmonic spectrum after load change being applied. It shows that the 
current harmonic distortion increases to $15.83 \%$ from 4.63 $\%$ and voltage harmonic distortion reaches $2.56 \%$ from 1.33 $\%$ as shown in Fig. 27.

\begin{tabular}{|l|l|l|l|}
\hline & Before PF & After PF & \% Reduction \\
\hline $3^{\text {rd }}$ & $2.3 \mathrm{~A}$ & $0.34 \mathrm{~A}$ & $85.21 \mathrm{~A}$ \\
\hline $5^{\text {th }}$ & $2.34 \mathrm{~A}$ & $0.08 \mathrm{~A}$ & $96.58 \mathrm{~A}$ \\
\hline $7^{\text {th }}$ & $1.75 \mathrm{~A}$ & $0.59 \mathrm{~A}$ & $66.28 \mathrm{~A}$ \\
\hline THD & $30.40 \%$ & $4.63 \%$ & 84.76 \\
\hline
\end{tabular}

FIG. 25 IMPROVEMENT IN LOAD CURRENT THD

\begin{tabular}{|l|l|l|l|}
\hline & Before PF & After PF & \% Reduction \\
\hline $3^{\text {rd }}$ & $5.3 \mathrm{~V}$ & $0.73 \mathrm{~V}$ & 86.22 \\
\hline $5^{\text {th }}$ & $8.42 \mathrm{~V}$ & $0.23 \mathrm{~V}$ & 97.26 \\
\hline $7^{\text {th }}$ & $8.67 \mathrm{~V}$ & $1.28 \mathrm{~V}$ & 66.78 \\
\hline THD & $5.96 \%$ & $1.33 \%$ & 77.68 \\
\hline
\end{tabular}

FIG. 26 IMPROVEMENT IN LOAD VOLTAGE THD

\begin{tabular}{|l|l|l|}
\hline & Load Current in \% & Load Voltage in \% \\
\hline $3^{\text {rd }}$ & 10.53 & 1.19 \\
\hline $5^{\text {th }}$ & 1.70 & 0.31 \\
\hline $7^{\text {th }}$ & 8.81 & 2.31 \\
\hline THD & 15.83 & 2.56 \\
\hline
\end{tabular}

Fig. 27 CHANGE IN LOAD CURRENT AND LOAD VOLTAGE DUE TO DETUNNING

\section{CONCLUSION}

Harmonic is the predominant power quality issue. Nonlinear domestic loads connected in the distribution system inject considerable current harmonics in the supply system resulting in $T H D_{I}$ ranging from $12.9 \%$ to $156.2 \%$ which violates the limits specified by IEEE 519 for current harmonic distortion.

Filtering is one of the solutions to prevent the harmonic from entering the rest of the system. Implementation of single tuned passive filter taking care of $3^{\text {rd }}, 5^{\text {th }}$ and $7^{\text {th }}$ harmonic, suppresses the $T H D_{I}$ by $84.76 \%$ and $T H D_{V}$ by $77.68 \%$.

Changed system configuration changes the harmonic profile of the system resulting in detuning, stating the limitation of passive filters.

\section{APPENDIX}

\section{A. Harmonic Voltage limits by IEEE 519}

\begin{tabular}{|l|l|}
\hline Bus Voltage in KV & THD $_{V}$ in $\%$ \\
\hline 69 \& above & 5.0 \\
\hline $115-161$ & 2.5 \\
\hline$>161$ & 1.0 \\
\hline
\end{tabular}

\section{B. Harmonic Current limits by IEEE 519}

\begin{tabular}{|l|l|}
\hline$S C R$ & THD in \% \\
\hline$<20$ & 5.0 \\
\hline $20-50$ & 8.0 \\
\hline $50-100$ & 12.0 \\
\hline $11-15$ & 20.0 \\
\hline
\end{tabular}

C. Designed Circuit Parameters used for simulation of non-linear load

\begin{tabular}{|l|l|l|l|}
\hline$V_{S}$ & $230 \mathrm{Volts}$ & $C_{L}$ & $100 \mu \mathrm{F}$ \\
\hline$f$ & $50 \mathrm{H}_{\mathrm{Z}}$ & $R_{L}$ & $20 \Omega$ \\
\hline$R_{S}$ & $1 \Omega$ & $V_{f}$ & 0.8 Volts \\
\hline$X_{S}$ & $2.2 \mathrm{mH}$ & & \\
\hline
\end{tabular}

\section{Designed Circuit Parameters used for simulation of} Passive Filters

\begin{tabular}{|l|l|l|l|l|l|}
\hline \multicolumn{2}{|c|}{ For $3^{\text {rd }}$ Harmonic } & \multicolumn{2}{|l|}{ For $5^{\text {th }}$ Harmonic } & \multicolumn{2}{l|}{ For $7^{\text {th }}$ Harmonic } \\
\hline$R \Omega$ & 0.1 & $R \Omega$ & 0.033 & $R \Omega$ & 0.017 \\
\hline$C \mu \mathrm{F}$ & 42.67 & $C \mu \mathrm{F}$ & 14.2 & $C \mu \mathrm{F}$ & 29.1 \\
\hline$L \mathrm{mH}$ & 26.4 & $L \mathrm{mH}$ & 28.51 & $L \mathrm{mH}$ & 7.4 \\
\hline
\end{tabular}

\section{ACKNOWLEDGMENT}

The authors gratefully acknowledge the contributions of Torrent Power PQ Cell, Surat for their assistance in field measurement of harmonic distortion,

\section{REFERENCES}

Papers from Conference Proceedings (Published):

[1] D. C. Bhonsle, Dr. R. B. Kelkar and N. K. Zaveri, "Power Quality Issues-In Distribution System", IE(I) $23^{\text {rd }}$ National Convention of Electrical Engineers, Pune, November 2007 Proceedings, pp. 108111.

[2] Dalila Mat Said Ahmed, Abdullah asuhaimi, Mohd Zin, "Power Supply Quality Improvement: Harmonic Measurement and Simulation," National Power and Energy Conference (PECon), 2003 Proceedings, Bangi, Malaysia, pp. 352-358.

[3] C. Gopalkrishnan, K Udaykumar, T. A. Raghvendiran, "Survey of Harmonic Distortion for Power Quality Measurement and Application of Standard including Simulation," 2001, Anna University, India.

[4] L. A. Moran, J. W. Dixon, J. R. Espinoza, R. R. Wallace, "Using Active Power Filter to Improve Power Quality", Santiago, Chile, 2000.

[5] K. C. Umeh, A. Mohamed, R. Mohmed, " Comparing The Harmonic Characteristics of Typical Single Phase Nonlinear Loads", National Power Energy Conference (PECon) 2003 Proceedings, Bangi, Malaysia, pp. 383-387.

Books:

[6] J. Arrillaga, D. A. Bradley, P. S. Bodger, "Power System Harmonics", New York: Wiley, 1985.

[7] E. Acha, M. Madrigal, "Power System Harmonics", Computer Modeling and Analysis, New York: Wiley, 2001.

[8] W. Mack Grady, Surya Santoso, "Understanding Power System Harmonics", IEEE Power Engineering Review, November, 2001.

Technical Reports:

[9] M. S. Lalli, I. P. S. Paul, “ Field Measurement of Power Quality in Steel Rolling Mills", Centerl Power Research Institute (CPRI), Banglore. Pp. 279-282.

[10] Fluke Corporation, "Common Power Quality Factors affecting Transformers", An Application Note, 2002.

[11] Marty Martin, P. E., "Two Modern Power Quality Issues- Harmonics and Grounding", an Article.

Standards:

[12] IEEE Recommended Practices and Requirements for Harmonic Control of Electrical Power Systems, IEEE Standards, 519, 1992, 1993. 